\title{
PURCHASE OF MULTIROLE FIGHTER AIRCRAFT FOR POLAND AS A GUARANTEE OF AIRSPACE SECURITY AND STRENGTHENING INTERNATIONAL POSITION
}

\author{
Marcin KALWAT, Lt. Pil. M.Sc.Eng. \\ Faculty of Management and Command \\ War Studies University \\ Al. gen. Antoniego Chruściela „Montera” 103, \\ 00-910 Warszawa, Poland \\ marcinkalwat@wp.pl
}

\section{Abstract}

The main goal of the paper is to analyze the current state of the combat aircraft in the Polish Air Forces, and on that account draw a conclusion regarding the potential need of purchasing a new multirole fighter in order to increase the national air defense capability.

The first section of the article is dedicated to a thorough description of the aircraft that constitute today the Polish Air Forces, i.e. the SU-22 "Fitter", MiG-29 "Fulcrum", and F-16 "Fighting Falcon". Advantages and disadvantages of each aircraft are presented and discussed.

The article is concluded with the statement that for the sake of the Polish airspace and overall security the country has to invest and acquire a new modern multi-purpose aircraft capable of performing a full range of combat missions.

Key words: multirole fighter aircraft, airspace security, SU-22, MiG-29, F-16

A good plan violently executed now is better than a perfect plan executed next week.

George S. Patton

\section{INTRODUCTION}

Joining the North Atlantic Treaty is invaluable in improving Poland's security. Thanks to the signing of the accession treaty, the Polish Armed Forces pledged to apply NATO military standards, which began a great deal of transformation of the army. Thanks to the participation of other countries in training and international missions, the Polish Armed Forces have achieved a very high level of interoperability. Thanks to its commitment and professionalism. Poland's international presence is appreciated and widely praised. ${ }^{1}$

Participation in NATO should not be recognized as a total guarantor of our security, but rather as a means supporting the national defense capabilities. ${ }^{2}$ Unfortunately, despite the numerous upgrades and purchases of new aircrafts, the situation of Polish military equipment is still not satisfying. We are still forced to use mostly post-Soviet equipment that would probably be useless in the contemporary battlefield. The Soviet weaponry that Poland possesses is often described by the old Polish-Russian proverb Gniotsja, nie tamiotsja, which translates into: it'll crumble but won't breake". Truth is, it does not contribute much to our actual combat capability. Soviet armament equipment that Polish Army is using at the moment generates lots of unnecessary costs related to, for example, the availability of the spare

1 www.www.msz.gov.pl

2 J. Marczak, „Potęga obronna Polski - fundamentem bezpieczeństwa narodowego Polski i Europy w XXI wieku", Obrona Narodowa, retrieved from: https://obronanarodowa.pl/artykuly/display/potga-obronna-polski-fundamentem-bezpieczenstwa-narodowego-polski-i-europy-w-xxi-wieku/ (22.10.2017). parts and their high cost (related indirectly to the option of purchasing them from Russia). The fact of having in use the post Soviet equipment imposes on the Polish military fighters the obligation to be trained on those machines, and hence, constituting the process of "technological backwardness".

The above generalization regarding the concept of the "soviet equipment" refers to vehicles, weapons and equipment, which are probably still present in all types of Polish Armed Forces. Armed Forces of the Republic of Poland, based on the security of our airspace, requires modernization of the equipment. Currently, the groundbased defense system of the Polish airspace is not sufficient to cover the area of the country without effective support from the aviation. Replacing the current fleet of combat aircraft used by the Air Force for state defense operations would strengthen the most important Polish defense - its combat potential. ${ }^{3}$ Such a purchase would contribute to the strengthening of the position of Poland in NATO, EU and gaining respect in the international arena among strategic partners.

\section{COMBAT AIRCRAFTS IN POLISH ARMED FORCES}

At present, there are three types of combat aircraft available in the Air Force:

- SU-22 (NATO Identification - Fitter) - 18 machines;

3 www.defence24.p 
- $\quad$ MiG-29 (NATO-Fulcrum designation) - 31 machines;

- F-16 (NATO- Fighting Falcon) - 48 machines.

The characteristics of these aircraft, in terms of their use in combat missions, will reveal the lack of equipment pilots can use during missions. Inadequate aircraft equipment limits the combat capability of the aircraft and often excludes them from performing real tasks during international exercises.

\section{The Su-22 Use Analysis}

The Su-22 "Fitter" (export version of the Soviet Su17) has been in the Polish army since 1974, when they were known for their innovations, both in terms of design, and their onboard systems. The use of the aircraft fighterbomber ideologically fits into the Warsaw Pact. ${ }^{4}$ This is a front wing aircraft that aims to combat ground and surface targets, mobile and stationary, and, to a limited extent, capable to combat maneuvering air targets. It can act as a reconnaissance and direct infantry support. ${ }^{5}$ In general (without going into detailed consideration of specific missions), one can assume that such tasks are being used by Polish troops.

Considering the tactical effectiveness of a combat aircraft, we must relate to the ability of this aircraft to perform its missions according to its purpose, taking into account the contemporary field and combat character. The Su-22 is an aircraft that is definitely underestimated by the public and forgotten during the modernization processes that has been taking place in the Polish army.

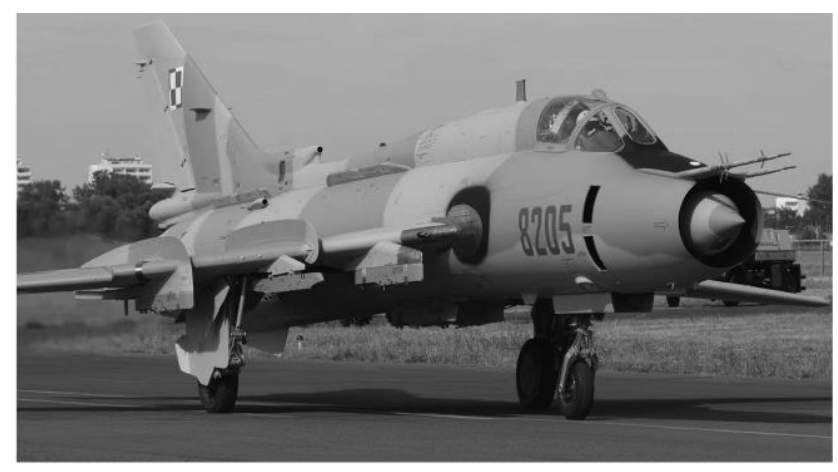

Fig. 1. Su-22 airplane from 21 Tactical Air Base in Swidwin. Photo: Michał Kuna

If we consider its effectiveness in attacking ground targets it can not be underestimated. Thanks to the NavigationalTargeting Complex, the PrNK-54 operates in two ranges, navigating and using parachute, unmanned missiles, bombs and guided missiles.

In terms of navigation, it provides a route-based flight based on geographic coordinates and a GPS Trimble 2101AP GPS receiver. The distance and bearing (angular position) of any of the entered points can be visualized on a translucent display. When flying over a given target, its coordinates can be memorized with the ability to automatically target it if the arming system is to be used. The system also provides a return to the home airport and landing maneuvers. Landing system up to 40-50 meters is indicated by the used beacon. With respect to the position of accuracy in navigation, the $\mathrm{Su}-22$ pilots praise their equipment.

The advantage for pilots would be to use a better navigation system, such as Multi Function Color Display, which MiG-29 from Mińsk Mazowiecki is equipped with. ${ }^{6}$

Such a navigation map would be helpful for flyovers during the Su-22 reconnaissance missions and for flyoffs. Regardless of the suitability, the modifications and upgrades of the Su-22 I mentioned before are not up- todate and should have been done around 15-20 years ago.

For the use of armament and aiming the Su-22 employs receivers GPS Trimble 2101AP supporting inertial complex PrNK-54, with viewfinder the S-17WG achieves a navigational accuracy of $50 \mathrm{~m}$.

In good weather conditions and with the use of the KLON-54 laser sight, the bomb load distribution is 30-40 m. The PrNK-54 also provides the use of targeted air-to-ground missiles (prohibited since 2008).

Blasting aerial targets at small and medium altitudes, with R-60 rockets are working out of the data for NR30 landings to attack air and land targets. ${ }^{7}$ The feature of the PrNK-54 is its autonomy, which results in immunity to interference as well as the radio-frequency detection, which obviously does not mean that it is an "undetectable plane" since its "undetectability" functions are exclusively within the scope described above.

Ergonomics of the cab in this machine is very different from the intuitive and "friendly" arrangement of instruments and differs from the modern aircraft.

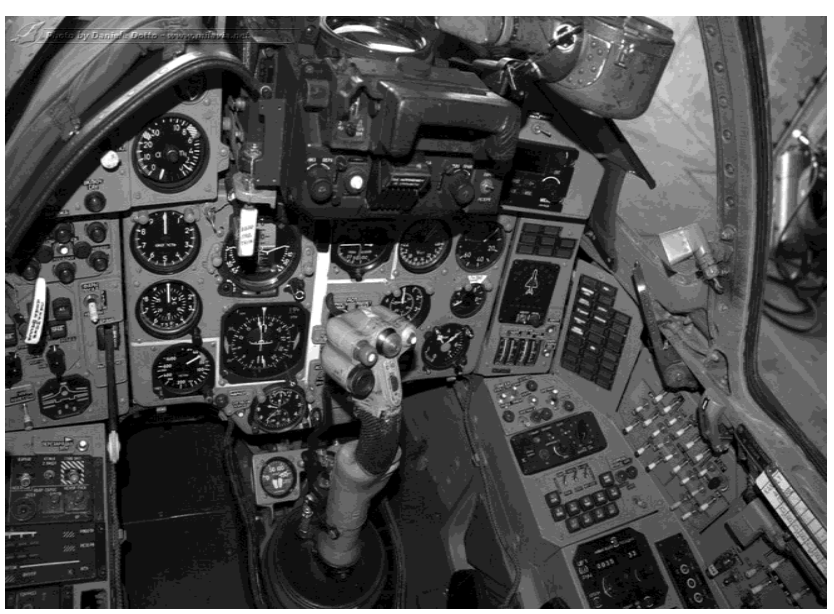

Fig. 2. Location of switches and instruments in the Su-22 cockpit. Source: www.milavia.net

The Su-22 does not have a radiolocation station, and only in the conditions of good visibility it can be armed with a relatively short range $\mathrm{R}-60$ rocket and a combat head. The above use of the radar for the $\mathrm{Su}-22$ would have been less important, but the radar function would be crucial in identifying threats that could be responded in time. 
Modern radars ensure low probability of interception (LPI) by appropriate beam irradiation technology and effective Electronic Counter-Counter Measures (ECCM). ${ }^{8}$

The Su-22 is in need of fighter support and radioshielding in the course of the strike. Without any support, sending Su-22M4 fighters with a combat mission on the modern battlefield would be a threat to the pilots' lives. The tactics of its use include a low-velocity, highvelocity flight that causes the AL-21F3's jet engine to consume extra fuel, necessity of suspension of additional fuel tanks in place of armaments. ${ }^{9}$ This limits the combat capabilities of the airplane that currently has no capacity for air refueling. Refueling in the air is used to provide greater range, longer flight time and full load capacity of a non-stop combat aircraft and is now an international standard among multi-role aircrafts. ${ }^{10}$

\section{Requests for the use by Poland of SU-22}

The ongoing modifications of the $\mathrm{Su}-22$ include the installation of a new $8.33 \mathrm{kHz}$ RS-6113 radio, the conversion of metric units to Anglo-Saxon, load monitoring systems, and repainting of the airframe. Changing the Su-22 camouflage for civil and military regulations is a way of unifying the color of the Polish fleet of military aircraft, but given the nature of the mission, it seems illogical. The work on the aircraft is ongoing, and its price (for repairs of 18 aircrafts) will rise up to 160 millions of PLN. ${ }^{11}$

Modification work on the Su-22 will not guarantee the improvement of Polish airspace security. As a result of the modernization work and the extension of the Su22 to 2025, the Air Force does not receive a better combat aircraft but an improved element of the military system primarily used in training (cooperation with other combat aircraft or air defense) and maintaining organizational continuity in the form of a base structure.

Although the Su-22 from Poland often appears during international exercises, its role is also limited due to the lack of the aircraft equipment. Polish Su-22 pilots, famed in Europe for the exemplary performance of the Close Air Support mission, do not have an easy task on this type of the aircraft. Buying a platform with the A-10 Thunderbolt II (the world's best-suited CAS mission plane) would be perfect, but the A-10's price and maintenance costs are too high for the US government. ${ }^{12}$ The idea to solve this problem could be the purchase of a multi-purpose aircraft that would allow direct support missions to replace the $\mathrm{Su}-22 .{ }^{13}$

8 www.radary.az.pl

9 www.dziennikzbrojny.pl

10 Ł. Pacholski, ,Samoloty tankowania powietrznego - dziś, jutro, pojutrze", Nowa Technika Wojskowa 12, pp. 74-82.

11 www.defence24.pl

12 L. Giangreco, "A-10 fleet spared retirement through 2021”, Fight

Global 07.02.2017, retrieved from: https://www.flightglobal.com/news/ articles/a-10-fleet-spared-retirement-through-2021-433927/, (20.10.2017). 13 www.flightglobal.com

\section{Use Analysis of MiG-29}

MiG-29 "Fulcrum" has been used by the Polish Air Force since 1989. After purchasing the aircraft from the USSR in subsequent years, Poland acquired additional aircrafts from the Czech Republic and Germany. MiG is a lightweight air superiority fighter intended for the USSR (later Russia) to supplement the Su-27. For many years this aircraft maintained the status of the "Air Combat Champion". Its high maneuverability is facilitated by its excellent aerodynamic layout, which in combination with the two RD-33 dual-jet engines makes it returnable and safe, even at low speeds and large attack angles.

The advantage of the MiG-29 is that it is more resistant than the F-16 to, for example, environmental factors ,such as precipitation, temperature, taxiway cleanliness and belt. It is also an easier plane than the F-16 in handling a logistical security.

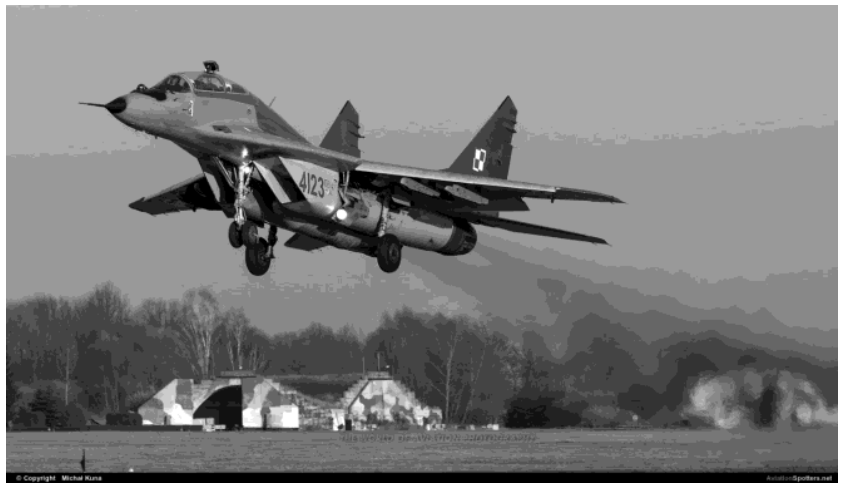

Fig. 3. MiG-29 aircraft from 22 Tactical Air Base in Malbork. Photo: Michał Kuna.

At present, the primary task of the MiG-29 is to carry out 24/7 combat duty over the territory of the Republic of Poland and to provide assistance to the military and civilian forces in case of emergency. The training of MiG-29 pilots due to the use of the unit is therefore focused on air combat and training with the capture of an aircraft.

A limited number of Mig-29 systems based on electronic systems can be viewed in two dimensions - as a small advantage, and at the same time the main drawback of the aircraft. The use of $\mathrm{EMP}^{14}$ arms emitting electromagnetic pulse on the contemporary battlefield is a subject that the US and Russia are avoiding. It is known however that such weapons have already been used. This creates an electromagnetic wave that induces large currents induced in the electronics, and destroys all unsecured components. ${ }^{15}$ The newest aircraft, which are all based on electronic circuits, are feared as they reverse the current development trend of the aircraft towards full digitization. Actually, looking at the Polish MiG-29, it will probably not have the opportunity to participate in such missions due to their inadequate combat capabilities and the lack of airto-air capability ( similar to $\mathrm{Su}-22$ ).

14 EMP weapon - weapon, based on an electromagnetic pulse. 15 www.defence24.pl 
MiG-29 is not equipped with the Link-16 tactical data transmission system used in NATO countries and allied US states. The implementation of this system has enabled the Polish F-16 to gain the ability to exchange data with AWACS early warning aircraft and transfer them to the NATO integrated defense system NATINAMDS. ${ }^{16}$ With Link-16 it is also possible to transfer data between planes, which during combat operations significantly improves the situational awareness on the battlefield during the groups combat. ${ }^{17}$

In spite of the high level of the training of Polish pilots on MiG-29 and good maneuverability of the aircraft, it is not possible to replace the advantages of the transmission of the information offered by this system.

The unintentional depiction on the display of Mig-29 radar station is not a big problem, however it is far from clear images with a large amount of information that contemporary combat aircraft provide. Continuing the topic of radars, they differ in sophistication and efficiency between the latest active electronically scanned radar, such as $\mathrm{AESA}^{18}$, and the Doppler radar station of the $80 \mathrm{~s}$ built into the MiG-29.

The warning of the aircraft radiated by both aircraft and ground anti-aircraft stations is provided by a multichannel amplitude sensor for the centimeter range of $Ł 006 \mathrm{M}$. This is an obsolete device that could have done its job if it had been updated to detect the newest threats.

Requests for use by Poland of MiG-29

The lack of equipment in MiG-29 directly affects the situational awareness (which plays a major role in the air combat), pilot safety and the success of combat operations.

The adaptation of the AIM-9X SIDEWINDER, AIM120C-5 AMRAAM, AGM-65G2 MAVERICK aircraft would reduce Polish dependence on the Russian armaments and increase the combat capability of our aviation by ensuring the compatibility between the armaments.

\section{Use Analysis of F-16}

F-16 Block 52 + Fighting Falcon has been used by the Polish Air Force since 2006. The contract involved the purchase of 36 single-seat F-16C fighters and 12 double- seat F-16D combat aircraft between 2006 and 2008. It is a multipurpose aircraft designed to perform air superiority combat missions, support other types of forces and conduct reconnaissance. This aircraft is the core of the Polish combat aviation.

16 NATO NATINAMDS - North Atlantic Treaty Organization Integrated Air and Missile Defense System.

17 www.defence24.pl

18 Northrop Grumman, "Northrop Grumman Successfully Completes F-22 Radar Flight-Test Certification", Northrop Grumman News 26.03.2007,

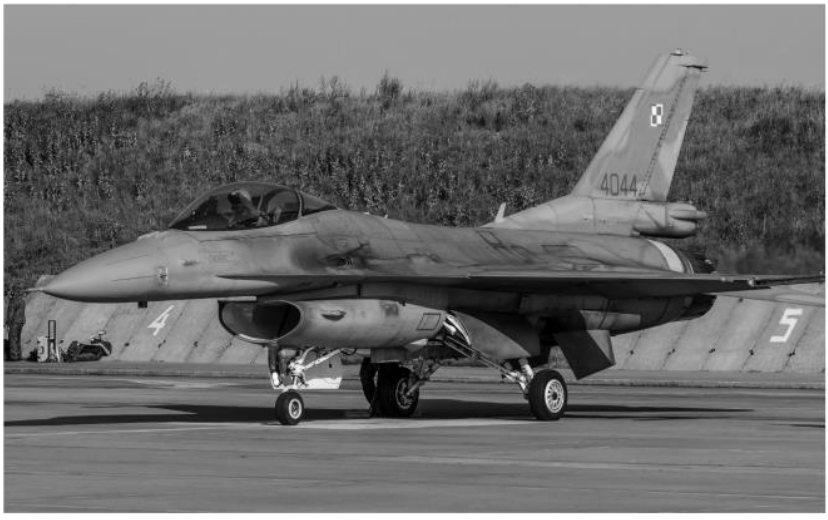

Fig. 4. Polish F-16 Block $52+$ at the airport parking plate in Malbork. Photo: Michał Kuna

Its advantages as a modern multi-purpose aircraft include:

- an extensive mission planning system,

- efficient and fast transfer as well as reception of the information between aircraft and ground stations via link-16,

- low level of radar, infrared, acoustic and visual identification,

- integrated on-board self-defense system,

- mirrored (reserve) on-board systems,

- multitasking and mission flexibility - ability to perform offensive and defensive missions in one flight and adaptation to combat missions in difficult weather conditions,

- long range (tactical radius of action, patrolling time),

- precise navigation,

- high accuracy and guaranteed destruction of the target,

- versatility of suspension points and high lifting capacity,

- ability to objectively evaluate the effectiveness of the actions,

- compliance with applicable NATO standards,

- $\quad$ air refueling. ${ }^{19}$ with:

In the field of armament the Polish F-16 are equipped

- radar-guided medium-range air-to-air missiles AIM120C-5 (AMRAAM);

- short-range missiles with infrared head AIM-9X Sidewinder;

- rocket-guided airborne IRM AGM-65G2 Maverick;

- JDAM-guided bombs guided by INS with GPS correction;

- Paveway II and III Bombs (GBU-12, laser guided GBU24);

- AGM-154C JSOW (Joint Standoff Weapon) guided GPSs;

- Mk82 bombs weighing $227 \mathrm{~kg}$,

- Mk84 bombs weighing $907 \mathrm{~kg}$,

- BDU-33 school bombs,

- cannon M61A1 20 mm. ${ }^{20}$

19 www.f-16.net

20 www.31blt.wp.mil.pl 
Requests for use by Poland of F-16

Acquisition by Poland of the multi-tasking F-16 Block $52+$ strengthened our position on the international scene. Airplanes from Krzesin and Grass take regular participation in international exercises Red Flag, Brte, Frisian Flag, Ramstein Guard. Currently (2017) they protect the Air Policing mission in the Baltic States. ${ }^{21}$ The eyes of the whole world are turned to the Operation Inherent Resolve as part of a global coalition to fight a terrorist group called DAESH, under the Charter of the United Nations, and at the request of the Iraqi government. The Polish F-16 has been actively involved in this operation since the beginning. ${ }^{22,23}$

The F-16 aircraft, from the very first days after purchase, are used extensively in the country and abroad, for training combat. F-16s in Poland are operated in terms of time in the air to the limits of their strength, and the limits of use of pilots as their operators. This implies a clear conclusion that Poland needs a lot more multitasking aircraft.

\section{PURCHASE OF MODERN MULTI-ROLE AIRCRAFT FOR POLAND}

Tactical targets are now being deployed throughout the world, which involves the withdrawal of specialized aircraft such as fighter-bombers, tactical bombers and fighter planes for multi-role aircraft with advanced electronic platforms capable of performing a full range of combat missions. This solution is particularly beneficial for states as it provides:

- unification of a fleet of used combat aircraft of one type,

- purchase fewer machines while maintaining combat capability,

- the ability to negotiate the prices of aircraft and spare parts when purchasing large quantities,

- the savings and benefits of training pilots and personnel operating one aircraft;

- cheaper operation of machines.

Defensive concept of national security strategy - conclusions for Poland

It is clear from the National Security Strategy of Poland that it is focused on defensive and peaceful actions. Point 74 of Chapter III defines the Polish approach to the subject of the strategy as follows: "The main tasks of the Armed Forces of the Republic of Poland, which give direction to planning and training in peace, concern the ability of the state to: defend and oppose aggression; To be prepared to carry out tasks related to the defense and protection of the integrity of the borders; Conducting strategic defense operations in the territory of the Republic of Poland; Participation in anti-terrorist activities in Poland and abroad; Participation in a defense operation outside the territory of the State corresponding to the Allied

\footnotetext{
21 www.lotniczapolska.pl

22 http://aviation24.pl

23 www.technowinki.onet.pl
}

obligations under Article 5 of the North Atlantic Treaty; Conducting reconnaissance and intelligence activities."

From the above quote it is clear that the purchase of new multipurpose planes for Poland should take into account the needs of defensive aviation. The standardization of the combat aircraft fleet will contribute to a more effective cooperation between the air squadrons in the common goal of defending the territory of the Republic of Poland.

Hypothetical threat situation of the Polish airspace

By analyzing the situation in which aircraft (without the support of anti-aircraft defense and NATO forces) of the Polish Air Force would have to face the sudden danger of hostile aviation, one should make a daring thesis that Poland would now turn out to be in this situation completely defenseless. There are arguments for this, starting with the weak defense strategy of aviation and ending with the outdated equipment.

\section{Proposals to buy a multipurpose plane for Poland}

The government is considering several options for the purchase of multi-purpose aircraft. One option is to purchase used F-16s and then upgrade them. This would involve very expensive and long work on airplanes and the adaptation of WZL No. 1 in Bydgoszcz. The cost of this investment is still being analyzed by the government.

Another option is the purchase of a new F-35 Lightning II multi-purpose aircraft. However, the barrier is the price of the aircraft (100-180 millions of PLN, depending on the package and selected version), as well as the feedback on problematic combat readiness, expensive operation and frequent malfunctions.

Poland is able to submit a Eurofighter GmbH consortium by offering a Eurofighter III triple fighter jet (manufactured in 2013 with the AESA Captor-E active phase scan antenna). The remaining offers include the NG version of Saab Gripen which, like the Eurofighter Typhoon, will be rejected by Poland for political involvement in relations with the United States of America and training of the Polish pilots over there.

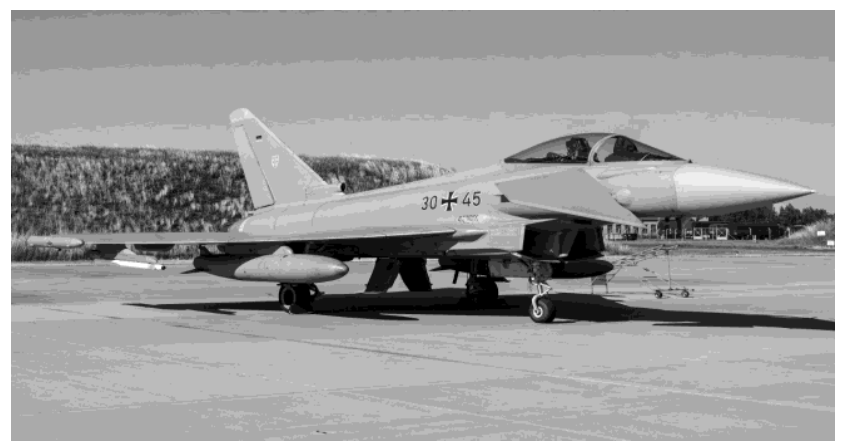

Fig. 5. Eurofighter Typhoon during practice at 22 BLT in Malbork. Photo: Michał Kuna

Comparing the parameters as well as the combat capabilities and equipment of the offered aircraft, taking 
into account the drawbacks and advantages of construction and operation, it would probably emerge as the winning aircraft, but these will not be the main criteria taken into account when it comes to this purchase. For a country with limited funds, three aspects will be important: political, financial, as well as the image.

\section{THE CONCLUSION OF THE ANALYZED AIRCRAFTS AND IMPACT ON SAFETY OF THE POLISH AIRSPACE}

The fact that the fleet of combat aircraft in Poland requires replacement (except for the F-16) is evident for pilots, their commanders and politicians. Maintaining Polish combat capability by replacing currently used machines should be a priority for the Ministry of National Defense. The prolonged length of time on the the organization of the tender and the attempt to draw public attention to unmanned aircraft negatively affect both the image of the Polish authorities and the potential for security.

The key to the security of Polish airspace should be a detailed analysis of the Air Force demand for new multitasking machines.

This tender should be preceded by a multifaceted analysis that takes into account the long-term prospects of using new combat aircraft, the efficient disposal of Air Force personnel, and the way the government will finance that purchase.

\section{BIBLIOGRAPHY}

1. Giangreco, L., A-10 fleet spared retirement through 2021, Fight Global 07.02.2017, retrieved from: https:// www.flightglobal.com/news/articles/a-10-fleet-sparedretirement-through-2021-433927/, (20.10.2017).

2. Marczak, J., Potęga obronna Polski - fundamentem bezpieczeństwa narodowego Polski i Europy w XXI wieku, Obrona Narodowa, retrieved from: https:// obronanarodowa.pl/artykuly/display/potga-obronna- polski-fundamentem-bezpieczenstwa-narodowegopolski-i-europy-w-xxi-wieku/ (22.10.2017).

3. Northrop Grumman, Northrop Grumman Successfully Completes F-22 Radar Flight-Test Certification, Northrop Grumman News 26.03.2007, retrieved from: https://news.northropgrumman.com/news/releases/ northrop-grumman-successfully-completes-f-22-radarflight-test-certification, (20.10.2017).

4. Pacholski, Ł. „Samoloty tankowania powietrznego dziś, jutro, pojutrze", Nowa Technika Wojskowa 12, pp. 74-82.

\section{WEBSITE RESOURSES}

1. Www.www.msz.gov.pl

2. www.defence24.pl

3. www.samolotypolskie.blogspot.com

4. www.eskadra.net

5. www.iu.wp.mil.pl

6. www.samolotypolskie.blogspot.com

7. www.radary.az.pl

8. www.dziennikzbrojny.pl

9. www.defence24.pl

10. www.f-16.net

11. www.31blt.wp.mil.pl

12. www.lotniczapolska.pl

13. www.aviation24.pl

14. www. technowinki.onet.pl

\section{FIGURES}

Fig. 1. Su-22 airplane from 21 Tactical Air Base in Swidwin. Photo: Michał Kuna

Fig. 2. Location of switches and instruments in the Su-22 cockpit

Fig. 3. MiG-29 aircraft from 22 Tactical Air Base in Malbork. Photo: Michał Kuna

Fig. 4. Polish F-16 Block $52+$ at the airport parking plate in Malbork. Photo: Michał Kuna

Fig. 5. Eurofighter Typhoon during practice at 22 BLT in Malbork. Photo: Michał Kuna 